\title{
PELATIHAN LAS PERINTIS PEMBUATAN PORTAL JALAN LINGKUNGAN RT.09/RW.07 KEL. MOOLANGU- KEC..LOWOKWARU KOTA MALANG
}

\author{
Santoso, Maskuri, R.N. Aksan Takwin, Sudarmadji, khambali, Sulistyono \\ Dosen Jurusan Teknik Mesin Politeknik Negeri Malang \\ santoso_polinema@yahoo.com
}

\begin{abstract}
Abstrak - Perkembangan daerah pemukiman di wilayah kodya Malang menambah jalur-jalur baru dan menimbulkan kerawanan, sehingga perlu pengawasan khusus untuk mengurangi tingkat kejahatan atau pencurian. Hal ini membutuhkan penjagaan ekstra atau membatasi jalur masuk dan keluar pada waktu-waktu tertentu, sehingga pengawasan lebih mudah dilakukan. Pembuatan portal untuk setiap block (gang) pada komplek perumahan merupakan hal penting dalam rangka mengurangi tingkat kejahatan/pencurian pada waktuwaktu tertentu, sehingga warga RT09/RW.07 Kelurahan Mojolangu sepakat untuk membuat portal mulai block 1 s/d block 5.
\end{abstract}

Kegiatan Pengabdian Kepada Masyarakat ini dapat dikategorikan pada program pemberdayaan masyarakat terhadap lingkungan dan hal ini perlu mendapat perhatian, karena beberapa hal antara lain, perlunya meningkatkan kepedulian masyarakat dalam ikut serta membangun lingkungannya, perlunya dana pendamping untuk menggali kemampuan masyarakat untuk membangun lingkungannya, dan perlunya meningkatkan kesadaran untuk menjaga fasilitas umum, sehingga tetap terpelihara, karena dengan terlibatnya dalam kegiatan ini berarti semua warga ikut memilikinya. Objek kegiatan ini adalah lingkungan yang menjadi jalan alternatif serta sering adanya kegiatan warga yang memanfaatkan jalan tersebut di lingkungan RT.09 / RW.07 Kelurahan Mojolangu. Tujuan yang ingin dicapai dalam kegiatan ini antara lain: meningkatkan kepedulian masyarakat dalam ikut menjaga lingkungan dari kemungkinan adanya kejahatan/pencurian, mengali kemampuan masyarakat untuk ikut serta membangun lingkungan yang konduksif, dan meningkatkan kesadaran masyarakat dalam hal pembuatan fasilitas umum khususnya portal jalan. Manfaat yang dapat diperoleh dalam kegiatan ini bagi warga dan masyarakat adalah terjadinya kerja sama sesama warga, dapat ikut serta dalam merencanakan kegiatan pembuatan portal jalan yang benar, dan dapat memperoleh portal jalan yang dapat digunakan atau dimanfaatkan di lingkungannya. Dalam pelaksanaan kegiatan Pengabdian Kepada Masyarakat ini metode yang digunakannya adalah melakukan observasi dan konsultasi kepada sebagian besar warga dalam kegiatan pertemuan rutin warga yang dilakukan setiap sebulan sekali, menyiapkan materi, persiapan alat, bahan, dan tempat yang diperlukan dalam membuat atau merakit portal jalan, proses bimbingan prosedur pembuatan portal jalan yang meliputi : (1). Rancangan awal portal jalan, (2). Standar warna (3). Ukuran panjang dan bebannya. Evaluasi akan dilakukan untuk melihat prosedur yang dijalankan dari anggota masyarakat atau peserta untuk setiap hasil kegiatan mulai awal sampai proses asembling dan hasil akhinya. Pada akhir pelaksanaan dilakukan dilakukan pemasangan ditempat yang sudah dimusyawarahkan secara bergotong royong.

Kata kunci: portal jalan, pelatihan, dan perintis.

\section{PENDAHULUAN}

\subsection{Analisis Situasi}

Perkembangan daerah pemukiman di kota maupun di daerah kabupaten menambah jalur-jalur baru yang membutuhkan petunjuk arah jalan khususnya pada jalan-jalan yang menuju tempat-tempat strategis yang ada di komplek perumahan maupun perkampungan, sehingga masyarakat umum tidak perlu banyak bertanya untuk menuju tujuan yang diharapkan dan juga dapat mengurangi tingkat kerawanan terhadap terjadinya kejahatan di lingkungan tersebut. Kondisi ini juga didukung dengan masih banyaknya anak-anak kecil yang bermain atau berlarian di jalan, sehingga sangat diperlukan peringatan-peringatan bagi pengendara kendaraan bermotor untuk lebih berhatihati guna mengurangai terjadinya sesuatu yang tidak diinginkan.

Adanya kegiatan warga yang sering terjadi dengan menutup jalan umum di daerah perumahan maupun perkampungan juga sangat diperlukan adanya tanda/rambu-rambu pemberitahuan, sehingga tidak banyak mengecewakan pengguna jalan. Hal seperti ini perlu mendapatkan perhatian dengan mengajak partisipasi warga setempat untuk lebih peduli terhadap lingkungannya, sehingga lingkungannya menjadi kondosif, nyaman, dan tidak memancing orang lain untuk berbuat yang tidak baik. Kepedulian warga dalam ikut serta memperpaiki lingkungannya memang perlu adanya penggerak guna menyadarkannya serta sedikit bantuan dana untuk pendamping, sehingga mempunyai kemauan untuk berpartisipasi baik berupa tenaga maupun materi.

Program ini dapat dikategorikan pada program pemberdayaan masyarakat terhadap lingkungan dan hal ini perlu mendapat perhatian dalam kegiatan pengabdian kepada masyarakat disebabkan beberapa hal antara lain:

1) Perlunya meningkatkan kepedulian masyarakat dalam ikut serta membangun lingkungannya.

2) Perlunya dana pendamping untuk menggali kemampuan masyarakat untuk membangun lingkungannya.

3) Perlunya meningkatkan kesadaran untuk menjaga fasilitas umum, sehingga tetap terpelihara, karena 
dengan terlibatnya dalam kegiatan ini berarti semua warga ikut memilikinya.

Lingkungan yang menjadi objek kegiatan ini adalah lingkungan yang menjadi jalan alternatif serta sering adanya kegiatan warga yang memanfaatkan jalan umum, sehingga memerlukan perhatian khusus untuk menggurangi ha-hal yang tidak baik seperti disebutkan di atas. Ikut serta menciptakan suasana lingkungan yang baik, merupakan salah satu cara untuk menggurangi terjadinya perbuatan kekerasan atau terjadinya tindak kejahatan, karena perbuatan tersebut dapat terjadi karena andanya niat yang tidak baik dan atau situasi lingkungan yang mendukung untuk melakukan perbuatan tersebut. Dalam hal ini kami sebagai warga masyarakat selayaknya ikut serta menciptakan suasana yang konduksif, sehingga kehidupan warga setempat dapat hidup aman dan nyaman.

\subsection{Rumusan Masalah}

Berdasarkan uraian permasalahan yang ada dapat dirumuskan beberapa permasalahan sbb :

1) Bagaimana meningkatkan kepedulian masyarakat dalam hal menjaga lingkungannya.

2) Bagaimana menggali kemampuan masyarakat untuk ikut serta membangun lingkungannya.

3) Bagaimana meningkatkan kesadaran masyarakat dalam membantu pengguna jalan dengan memasang tanda arah dan rambu-rambu jalan.

\section{TINJAUAN PUSTAKA}

\subsection{Peralatan Tangan}

Bekerja di bengkel mekanik hampir selalu berhubungan dengan pekerjaan mengikir di samping pekerjaan yang lain. Mengikir adalah suatu pekerjaan dalam proses pengikiran/pemotongan permukaan benda kerja oleh gigi-gigi kikir. Kikir terbuat dari baja tempa yang mengandung karbon tinggi dan meliputi bagian panjang, potongan, bentuk dan gigi pemotong. Jika ditinjau dari bentuknya, ada beberapa tipe yang sering kita jumpai, antara lain bentuk flat, square, triangular or tree square, round, half round, dan elliptica.

Selain mengikir, pekerjaan di bengkel mekanik yang paling sering kita jumpai adalah pekerjaan menggergaji. Alat yang digunakan untuk menggergaji disebut gergaji. Gergaji digunakan untuk memotong atau untuk mengurangi ketebalan suatu benda kerja. Ada beberapa tipe gergaji jika ditinjau dari bingkai dan daun gergaji yang ada di pasaran. Lebar dan tebal daun gergaji tangan pada umumnya bergigi tunggal. Sifatnya kaku dan mudah patah. Banyaknya gigi antara 6-14 gigi tiap incinya. Letak giginya bersilang-silang (zig-zag),

\subsection{Pengelasan}

Proses pengelasan berfungsi untuk menyambungkan antara dua logam dengan cara mencairkan kedua logam yang akan di sambung dan bahan tambahnya (elektodenya). Kegiatan ini sebaiknya dilakukan oleh orang yang telah berpengalaman dalam hal proses pengelasan dan warga atau orang yang menginginkan ketrampilan ini sebaiknya harus menjalani training lebih dahulu, baik teknik pengelasannya maupun sistem keselamatan dan kesehatan kerjanya. Pekerjaan pengelasan memiliki resiko khususnya pada mata, karena adanya sinar ultraviolet sehingga pekerja harus menggunakan topeng las dan pernafasan maupun percikan api, sehingga pekerja juga harus menggunakan apron dari kulit dan masker.

Mesin las ini mengeluarkan tegangan yang cukup rendah, sehingga pekerja tidak akan tersengat aliran listrik, tetapi akan mengeluarkan arus yang cukup tinggi ampernya untuk dapat mencairkan logam. Besarnya arus dapat diatur sesuai kebutuhan yang disesuaikan dengan ketebalan material yang akan di las atau diameter elektroda yang akan digunakan. Semakin besar arus yang digunakan akan cepat material itu dapat mencair dan proses pengelasannya juga semakin mudah atau tidak mudah lengket.

Teknik penyambungan kabel las harus cukup kuat untuk menghidari terjadinya panas, karena arus yang mengalir sangat besar. Kabel harus cukup fleksibel (tidak kaku) untuk memudahkan proses pengelasan. Pada umumnya terbuat dari tembaga, sehingga konduktivitas panas dan listrik sangat baik serta tahan terhadap proses korosi.

\subsection{Pengecatan}

Mempersiapkan permukaan yang akan dicat dengan baik akan menghasilkan kualitas pengecatan yang maksimal, karena pada umumnya kagagalan pengecatan dipengaruhi oleh persiapan permukaan yang buruk. Indikator dari permukaan yang baik dinilai dari kehalusan permukaan, kebersihan permukaan dari karat, lemak dan kotoran lainnya. Persiapan permukaan dapat dilakukan dengan kimiawi misalnya dengan pengasaman (pickling) yaitu dengan pengolesan benda yang akat di cat (obyek) dengan zat asam, tetapi pengasaman ini sebatas untuk menghentikan serangan korosi pada logam. Setelah pengasaman obyek dicuci dan dikeringkan dengan cermat guna menghilangkan semua bahan kimia aktif dari celah-celah dan lubang-lubang, serta untuk menjamin agar cat dapat merekat erat pada logam. Cara lain adalah dengan dibersihkan dengan amplas dan dikombinasikan dengan semprotan air untuk membasuh semua debu, menghilangkan produk korosi, dan kotoran yang dapat larut dalam air.

Dempul digunakan untuk mengisi bagian yang tidak rata atau penyok dalam, membentuk suatu bentuk dan membuat permukaan halus. Pengolesan dempul dilakukan setelah permukaan dibersihkan dari debu, gemuk minyak, air dan kotoran lain. Selanjutnya mencampur dempul dengan $2 \%$ hardener. Kemudian mengoleskan tipis-tipis secara merata (maksimal 5 $\mathrm{mm}$ ), dan kemudian dikeringkan pada udara biasa atau dioven dengan suhu $50^{\circ} \mathrm{C}$ selama 10 menit. Setelah dempul kering kemudian digosok dengan kertas gosok untuk mendapatkan permukaan yang rata dan halus.

\section{TUJUAN DAN MANFAAT}




\subsection{Tujuan}

Tujuan yang ingin dicapai dalam kegiatan Pengabdian Kepada Masyarakat ini adalah sebagai berikut :

1) Meningkatkan kepedulian masyarakat dalam hal memberikan informasi pada pengguna jalan.

2) Mengali kemampuan masyarakat untuk ikut serta membangun lingkungan yang konduksif.

3) Meningkatkan kesadaran masyarakat dalam hal pembuatan fasilitas umum khususnya tanda arah jalan dan rambu-rambu jalan.

\subsection{Manfaat}

Manfaat yang dapat diperoleh dalam kegiatan Pengabdian kepada Masyarakat ini bagi warga dan masyarakat adalah :

1) Terjadinya kerja sama sesama warga, sehingga tercipta kerukunan dalam membangun atau pembuatan fasilitas umum.

2) Dapat mengetahui prosedur yang benar dalam merencanakan kegiatan pembuatan tanda arah jalan dan rambu-rambu jalan yang benar.

3) Dapat memperoleh tanda arah jalan dan ramburambu jalan yang dapat digunakan atau dimanfaatkan di lingkungannya.

\section{METODE DAN EVALUASI}

\subsection{Metode PKM}

Dalam pelaksanaan kegiatan Pengabdian Kepada Masyarakat ini metode yang digunakannya adalah sebagai berikut.

1) Melakukan observasi dan konsultasi kepada sebagian besar warga dalam kegiatan pertemuan rutin warga yang dilakukan setiap sebulan sekali.

2) Menyiapkan materi, persiapan alat, bahan, dan tempat yang diperlukan dalam membuat atau merakit tanda arah jalan dan rambu-rambu jalan.

3) Proses bimbingan prosedur pembuatan tanda arah jalan dan rambu-rambu jalan yang meliputi : (1). Rancangan awal dari bentuk rambu-rambu, (2). Standar warna gambar dan tulisan. (3). Ukuran panjang dan lebar yang diinginkan (mengacu ukuran standar jika ada),

4) Penyusunan laporan kegiatan PKM.

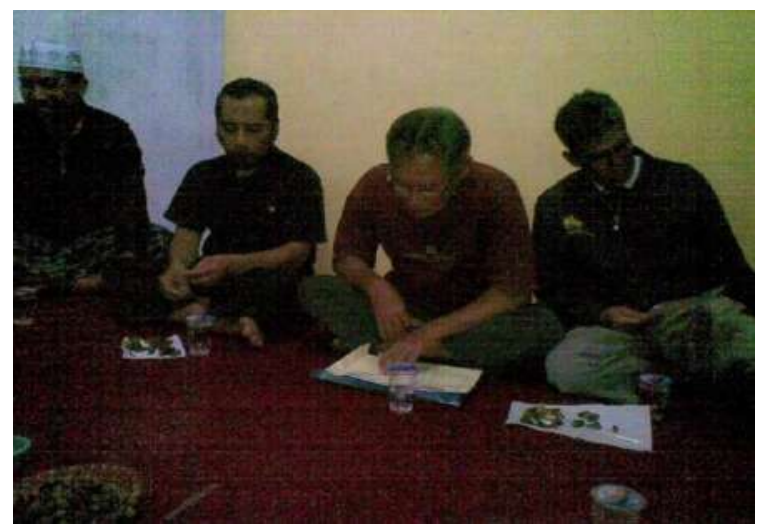

Gambar 1 Saat pertemuan warga
Penjelasan rencana kegiatan Pengabdian Kepada Masyarakat pada saat pertemuan rutin warga RT.09 / RW.07 Kelurahan Mojolangu seperti terlihat pada gambar 1. Pada pertemuan ini diperoleh masukanmasukan dari warga seperti kesepakatan untuk memberlakukan jalur satu arah untuk jalan di blok I, II, dan III. Semua kendaraan dari selatan akan melewati blok II dan kendaraan yang dari utara yang akan menuju perumahan Griya Shanta atau jalan Sukarno Hatta bisa melewati blok I atau blok III. semua kendaraan yang memasuki daerah perumahan dihimbau untuk jalan pelan-pelan, karena banyak anak-anak kecil dan untuk mengurangi timbulnya debu yang berlebihan.

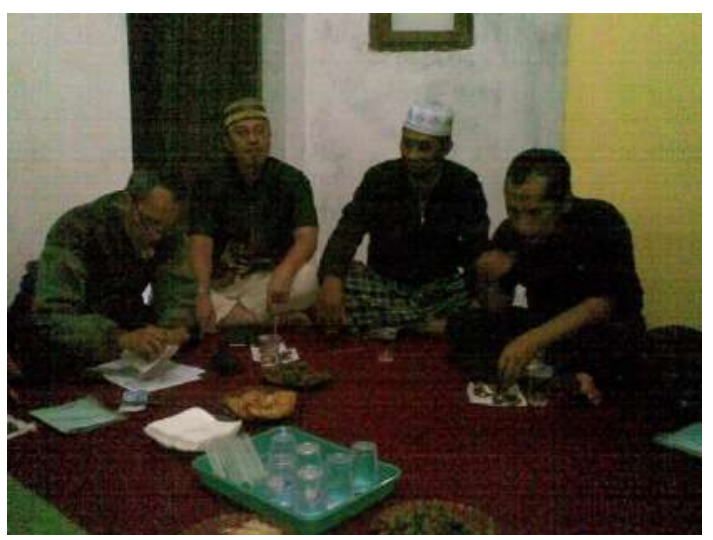

Gambar 2 Saat diskusi tanda-tanda yang akan dibuat

Diskusi tentang bentuk himbauan dan tanda ramburambu yang akan dipasang khususnya di setiap ujung jalan di blok I, II, dan III adalah terlihat seperti pada gambar 2. Pada pertemuan ini diperoleh masukanmasukan dari warga tentang rancangan petunjuk jalan dan rambu-rambu jalan, kemudian disepakati untuk setiap hari libur (minggu) untuk melakukan kerja bakti menyelesaikan apa yang telah direncanakan dan sepakati bersama. Teknik pembuatan atau prosedur pembuatannya juga didiskusikan bersama, supaya kerjannya nanti lebih efisian dan mengurangi terjadinya kesalahan, karena dalam bekerja nantinya melibatkan banyak orang dan semua orang belum tentu memahami prosedur pembuatannya

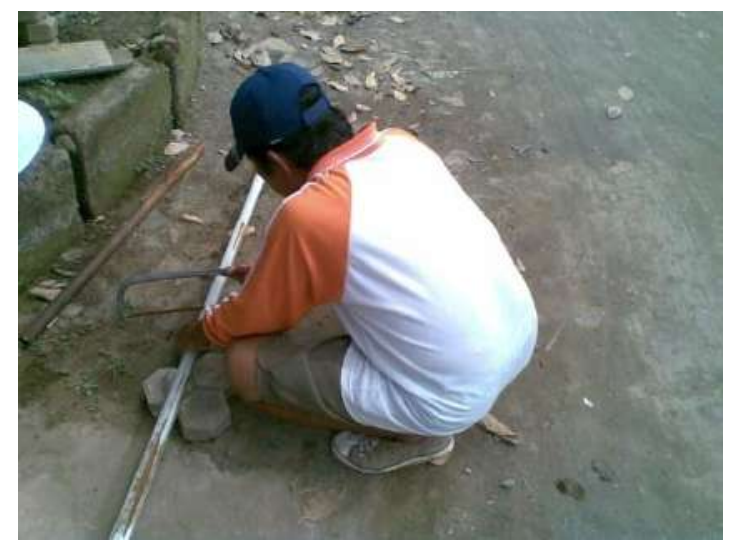

Gambar 3 Pemotongan pipa untuk tiang 
Dalam proses pembuatan semua warga diharapkan berpartisipasi, sehingga dalam pelaksanaan kegiatan Pengabdian Kepada Masyarakat, selain masyarakat mendapatkan barang yang diinginkan juga akan terjalin kerukunan dan timbul sifat yang saling tolong menolong atau berjiwa gotong royong. Gambar 3 adalah salah satu warga yang ikut berpasipasi dalam kegiatan Pengabdian Kepada Masyarakat dengan melakukan pemotongan pipa untuk tiang petunjuk nama jalan dan tanda himbauan bagi pengendara kendaraan

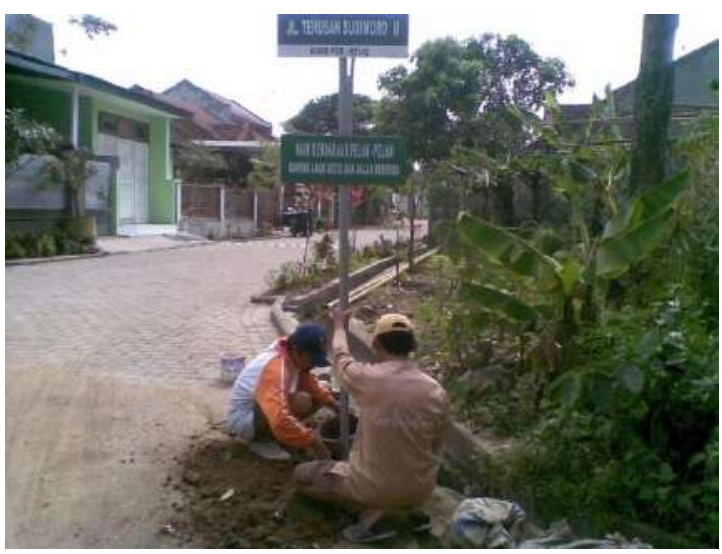

Gambar 4 Pemasangan petunjuk jalan

Setelah proses pembuatan petunjuk nama jalan dan tanda himbauan bagi pengendara kendaraan keduanya dipasangkan pada satu tiang dan selanjutnya dipasang pada tempat sesuai dengan rencana awal. Gambar 4 adalah salah satu kegiatan warga yang memasang tiang petunjuk jalan dan tanda himbauan di blok II bagian ujung selatan dengan dicor supaya lebih kuat dan tidak mudah korosi. Kegiatan pemasangan tiang tanda pentunjuk jalan seperti ini dilakukan oleh beberapa warga disetiap ujung jalan di blok I, II. dan III. Persiapan yang harus dilaukan warga sebelum proses pemasangan tiang tanda pentunjuk jalan adalah membuat adonan pasir, oral (batu kerikil), semen, dan air secukupnya.

\subsection{Evaluasi}

Evaluasi akan dilakukan untuk melihat prosedur yang dijalankan dari anggota masyarakat atau peserta untuk setiap hasil kegiatan mulai awal sampai proses asembling dan hasil akhinya. Pada akhir pelaksanaan dilakukan dilakukan pemasangan ditempat yang sudah dimusyawarahkan secara bergotong royong.

\section{HASIL DAN PEMBAHASAN}

\subsection{Faktor Pendukung}

Selama kegiatan Pengabdian Kepada Masyarakat ini berlangsung ada beberapa faktor yang mendukung, sehingga program ini dapat berlangsung dengan baik. Adapun faktor-faktor pendukung tersebut adalah telah tersedianya sebagian sarana dan prasarana yang dibutuhkan dalam proses pembimbingan :

1) Las busur listrik, karena ada salah satu warga yang mempunyai sehingga bisa meminjamnya.
2) Perlatan tangan seperti, gergaji besi, kikir, palu, mesin bor tangan, dll sudah ada, karena sebaian warga ada yang mempnyai sehingga dapat meminjamnya untuk keperluan kegiatan PKM.

3) Adanya kerja sama yang baik dari sebagian warga yang mempunyai kepedulian terhadap kebaikan lingkungannya.

4) Adanya peralatan yang ada di bengkel di Jurusan Teknik Mesin Polinema yang dapat di pinjam atau digunakan untuk membantu kegiatan PKM ini seperti, mesin potong plat,

5) Adanya sebagian material atau bahan yang masih dapat digunakan untuk kegiatan PKM ini seperti, pipa untuk tiang penyangga, material bangunan seperti pasir, oral, dll.

\subsection{Hambatan}

Hambatan pada umumnya terletak pada padatnya kegiatan belajar mengajar bagi semua team kegiatan Pengabdian Kepada Masyarakat dan tugas-tugas lainnya seperti penelitian dan bimbingan mahasiswa DIII yang sedang menyelesaikan laporan akhir, atau mahasiswa DIV yang sedangan menyelesaikan skripsinya. Selanjutnya kegiatan Pengabdian Kepada Masyarakat dalam hal pembuatan petunjuk nama jalan dan rambu-rambu oleh anggota masyarakat hanya bisa dilakukan pada hari minggu atau hari libur nasional, karna di hari-hari biasa hampir semua anggota masyarakat kerja.

\subsection{Hasil yang Diperoleh}

Berdasarkan rencana program pelaksanaan kegiatan Pengabdian Kepada Masyarakat di proposal dan hasil musyawarah warga diperoleh kesepakatan bahwa :

1) Demi keselamatan dan kelancaran arus lalu lintas yang melalui jalan di blok (gang) I, II, dan III, maka dibuat ketentuan jalur satu arah di ketiga jalan tersebut.

2) Kendaraan yang menuju arah ke utara harus melewati blok II dan kendaraan yang menuju ke selatan harus melewati blok I atau III.

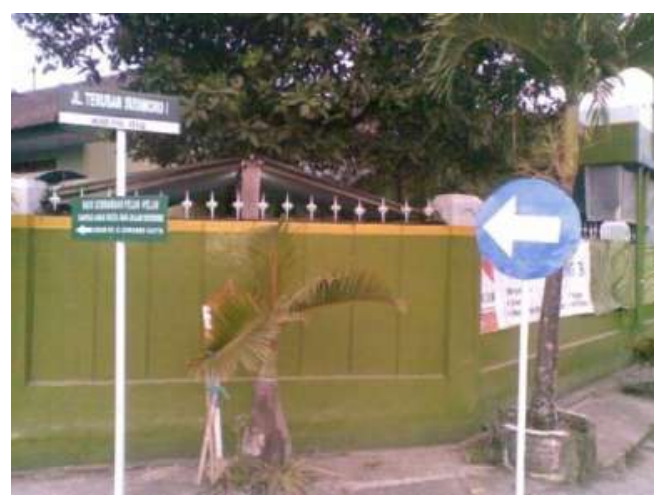

Gambar 5. Petunjuk arah yang diwajibkan yang terpasang sebelah utara Blok

3) Untuk semua kendaraan dihimbau untuk jalan pelan-pelan karena banyak anak-anak dan untuk mengurangi timbulnya debu yang berlebihan. 
4) Pada ujung blok I sebelah utara akan di pasang petunjuk nama jalan dan tanda petunjuk arah seperti gambar 5 .

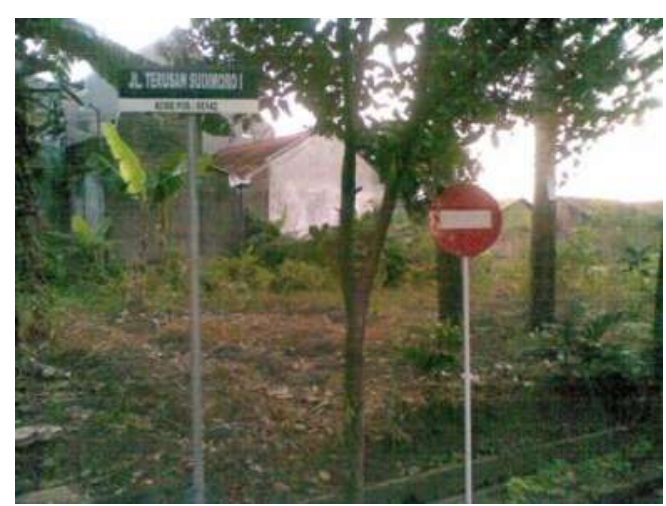

Gambar 6 Rambu-rambu dilarang masuk yang terpasang Blok 1 sebelah selatan

5) Pada ujung blok I sebelah selatan akan di pasang petunjuk nama jalan dan rambu-rambu dilarang masuk seperti gambar 6 .

6) Pada ujung blok II sebelah utara akan di pasang petunjuk nama jalan dan rambu-rambu seperti gambar 7.

7) Pada ujung blok II sebelah selatan akan di pasang petunjuk nama jalan dan petunjuk arah yang diwajibkan seperti gamabar 8. untuk mewajibkan kendaraan dari arah selatan untuk melewati blok II atau menuju blok IV dan V.

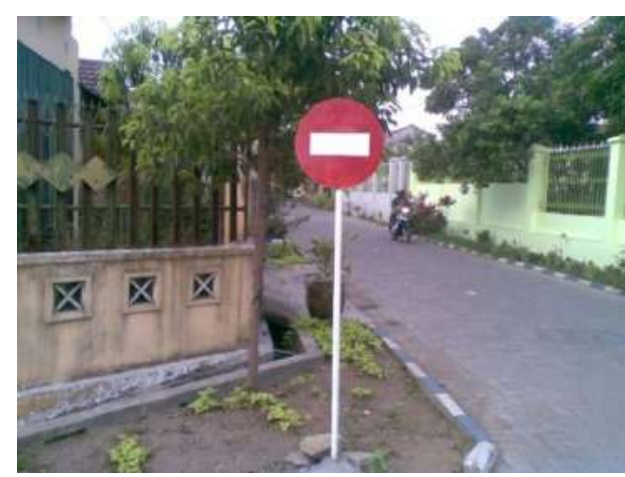

Gambar 7 Rambu-rambu dilarang mauk yang terpasang sebelah utara Blok II

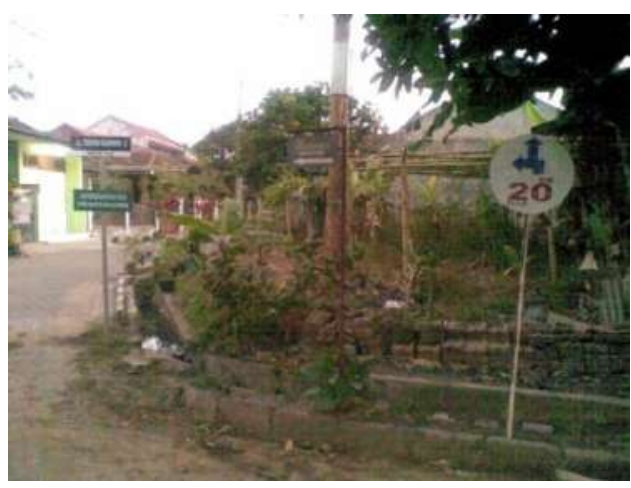

Gambar 8 Petunjuk arah yang diwajibkan yang terpasang Blok II sebelah selatan
8) Pada ujung blok III sebelah utara akan di pasang petunjuk nama jalan tanda petunjuk arah yang diwajibkan, sebagai petunjuk semua kendaraan dari arah barat dapat belok kekanan untuk melewati blok III untuk menuju perumahan Griya Shanta atau jl. Sukarno Hatta atau lurus menuju jalan Sudimoro.

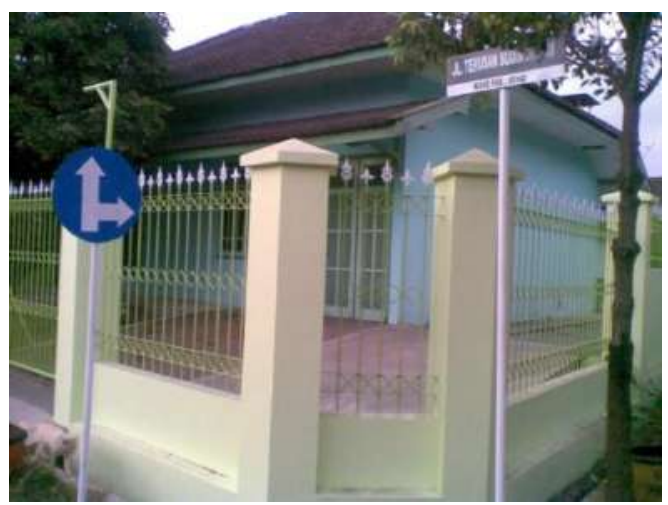

Gambar 9. Petunjuk arah yang diwajibkan yang terpasang di Blok III sebelah Utara

9) Pada ujung blok III sebelah selatan akan di pasang petunjuk nama jalan Terusan Sudimoro III. kode pos 65142, dan tanda stop untuk semua jenis kendaraan bermotor.

10) Rancangan untuk semua petunjuk jalan akan dibuat pada plat aluminium dengan ukuran $5 \mathrm{x}$ $220 \times 650 \mathrm{~mm}$, warna cata dasar biru dan warna tulisan putih (sesuai warna standar untuk petunjuk jalan). Adapun rancangan / desain tulisannya adalah sebagai berikut :

\section{KESIMPULAN DAN SARAN}

\subsection{Kesimpulan}

Berdasarkan proses kegiatan pengabdian kepada masyarakat dapat di ambil beberapa kesimpulan sebagai berikut :

1. Diperlukan komunikasi yang baik pada anggota masyarakat melalui pertemuan warga dalam kegiatan PKM.

2. Perlunya dana pendamping untuk menggerakkan kepedulian masyarakat terhadap lingkungannya.

3. Keterlibatan anggota masyarakat sangat diperlukan untuk mengefektikan kegiatan.

\subsection{Saran}

1. Perlu adanya peningkatan kegiatan PKM pada kelompok masyarakat yang produktif guna meningkatkan perekonomian masyarakat.

\section{DAFTARPUSTAKA}

[1]. Subagijo, 2012, Module Praktek Las, Teknik Mesin Polinema

[2]. Kasijanto 2012, Module Teknik Bengkel, Teknik Mesin Polinema 